\title{
HPLC-FTIR spectroscopy combined with multivariate calibration for analysis of Andrographolide in Andrographis paniculata extract
}

\author{
Abdul Rohman ${ }^{1,2^{*}}$, Hanifah Luthfianasari², Irnawati ${ }^{3}$, Sugeng Riyanto ${ }^{2}$, Mohamad Rafi ${ }^{4}$, Bambang Prajogo $^{5}$, Muhammad \\ Bachri Amran ${ }^{6}$ \\ ${ }^{1}$ Center of Excellence Institute for Halal Industry \& Systems, Universitas Gadjah Mada, Yogyakarta 55281, Indonesia. \\ ${ }^{2}$ Department of Pharmaceutical Chemistry, Faculty of Pharmacy, Universitas Gadjah Mada, Yogyakarta 55281, Indonesia. \\ 3Faculty of Pharmacy, Halu Oleo University, Kendari 93232, Indonesia. \\ 4Department of Chemistry, Faculty of Mathematics and Natural Sciences, Institut Pertanian Bogor. Jl. Tanjung Kampus IPB Dramaga, Bogor 16680, West \\ Java, Indonesia. \\ 5Department of Pharmacognosy and Phytochemistry, Faculty of Pharmacy, Universitas Airlangga. Jl. Mulyorejo, Kampus C Unair, Surabaya 60286, East \\ Java, Indonesia. \\ 6Analytical Chemistry Research Group, Institut Teknologi Bandung. Jl. Ganesha No. 10, Bandung 40132, West Java, Indonesia.
}

\begin{tabular}{|c|c|}
\hline ARTICLE INFO & ABSTRACT \\
\hline $\begin{array}{l}\text { Received on: } 11 / 06 / 2020 \\
\text { Accepted on: } 19 / 12 / 2020 \\
\text { Available online: } 05 / 05 / 2021\end{array}$ & $\begin{array}{l}\text { Andrographis paniculata, known as Sambiloto in Indonesia, has been reported to have pharmacological activities } \\
\text { with the main active constituent being andrographolide (ANDR). The present study highlighted the research for } \\
\text { determining the levels of ANDR by correlating the absorbances of Fourier transform infrared (FTIR) spectra with } \\
\text { ANDR contents as quantitatively analyzed by reference method of High-performance liquid chromatography (HPLC) }\end{array}$ \\
\hline $\begin{array}{l}\text { Key words: } \\
\text { Andrographis paniculata, } \\
\text { FTIR spectra, HPLC, PLSR, } \\
\text { multivariate calibration. }\end{array}$ & $\begin{array}{l}\text { using multivariate calibrations. Andrographis paniculata herbs from several regions were powdered. The powdered } \\
\text { samples were measured in terms of FTIR spectra. Besides, a weighted sample was subjected to the extraction procedure } \\
\text { and measured using HPLC. Data obtained are subjected to multivariate calibrations. The result indicated that the } \\
\text { method was useful to evaluate ANDR content in } A \text {. paniculata herb. Partial least square regression (PLSR) using } \\
\text { FTIR spectra in the form of a second derivative at the wavenumber regions of } 3,700-665 \mathrm{~cm}^{-1} \text { was finally preferred } \\
\text { for the quantitative analysis of ANDR with Coefficient of determination }\left(R^{2}\right) \text { values of } 0.9997 \text { in the calibration model } \\
\text { and } 0.9765 \text { in the validation models. The values of Root mean square error of calibration (RMSEC) and Root mean } \\
\text { square error of prediction (RMSEP) obtained were } 0.005 \text { and } 0.055 \text {, respectively. Due to its capability of providing a } \\
\text { high value of } R^{2} \text { and low values of RMSEC and RMSEP, the application of PLSR using the variable of FTIR spectra } \\
\text { at selected conditions could be an effective alternative method for quantitative analysis of ANDR. }\end{array}$ \\
\hline
\end{tabular}

\section{INTRODUCTION}

Andrographolide (ANDR), having the chemical structure as shown in Figure 1, is a member of diterpenoid compounds, mainly isolated from $A$. paniculata belonging to the Acanthaceae family. This plant is known as the "King of Bitters." In Indonesia, A. paniculata is known as "Sambiloto," one of the medicinal plants extensively studied because of some beneficial health

\section{${ }^{*}$ Corresponding Author}

Abdul Rohman, Faculty of Pharmacy, Gadjah Mada University,

Yogyakarta,Indonesia.E-mail: abdul_kimfar@ugm.ac.id effects (Akowuah et al., 2009). In traditional medicine, especially in Asian countries, Sambiloto is widely used to treat fever, cold, laryngitis, and infections. The extracts and fractions of Sambiloto containing ANDR have been evaluated for the biological activities including antioxidant (Akowuah et al., 2008), hepatoprotector from cell death induced by hydrogen peroxide (Mittal et al., 2016), carbon tetrachloride (Chen et al., 2014), inducer of glutathione S-transferase pi class (Lu et al., 2011), inhibitor of inflammatory responses in lipopolysaccaride-stimulated macrophages (Kim et al., 2019), and to have antidiabetic activities (Xu et al., 2012). These activities are correlated with phytochemical contents present in A. paniculata, mainly ANDR; therefore, analytical methods 


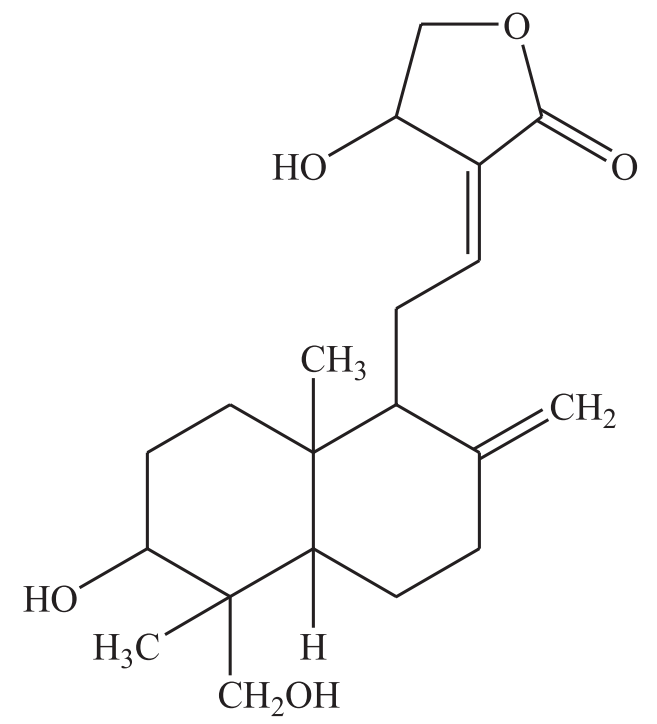

Figure 1. The chemical structure of andrographolide (ANDR).

capable of a fast and reliable technique for the determination of ANDR are continuously developed, validated, and applied in any type of sample matrices.

Several methods have been applied for quantitative analysis ofANDR, and the most reported ones are chromatographicbased methods. High-performance liquid chromatography (HPLC) using detector UV $224 \mathrm{~nm}$ has been used for purity analysis of ANDR and ANDR quantification in bulk materials (Indrati et al., 2018) and HPLC using detector UV $210 \mathrm{~nm}$ has been used for the analysis of ANDR in methanol extract of $A$. paniculata. Liquid chromatography-mass spectrometry has also been widely used for the analysis of ANDR in extracts and biological fluids (Gu et al., 2007; Sajeeb et al., 2015; Xu et al., 2009; Zhang and Fan, 2012). The other methods used for ANDR quantification are thin layer chromatography (Akowuah et al., 2006), electrokinetic chromatographic (MEEKC) method (Yanfang et al., 2006), and proton NMR-spectroscopy (Yang et al., 2012). These methods involve sophisticated instruments, complex sample preparation, and skillful analyst; therefore, a reliable method offering accurate and precise results based on Fourier transform infrared (FTIR) spectra could be developed as an alternative method for the determination of ANDR.

FTIR spectra were reported for characterization of vibrational properties of ANDR extracted from $A$. paniculata (Singh et al., 2006) and for confirmation and qualitative analysis of ANDR. FTIR spectroscopy has been successfully used for the analysis of total lactones in dried and powdered A. paniculata (Shivali et al., 2012). To the best of our knowledge, FTIR spectra in conjunction with chemometrics of multivariate analysis for quantitative analysis of ANDR have not been reported as yet (Indrati et al., 2018). Therefore, in the present research, FTIR spectra assisted with Partial least square regression (PLSR) was used for the prediction of ANDR. The levels of ANDR quantified by HPLC were used as actual values to be correlated with predicted values obtained from FTIR spectra with the aid of multivariate calibration.

\section{MATERIALS AND METHODS}

\section{Materials}

The samples of $A$. paniculata herbs (15 samples) were obtained from several regions in Daerah Istimewa Yogyakarta, West Java, and Central Java (Bantul, Sleman, Kulon Progo, Semarang, Boyolali, and Bogor), Indonesia. The plant identification was carried out in the Laboratory of Pharmacognosy and Phytochemistry, Faculty of Pharmacy, UGM, Yogyakarta. The reference standards of ANDR and methanol HPLC grade were purchased from Merck (Darmstadt, Germany). Water for injection was bought from Ikapharmindo (Indonesia). The chemicals used for the analysis were of a pro analytical grade.

\section{Samples' extraction}

The herbs of $A$. paniculata were cleaned and chopped into pieces. The chopped herbs were dried in a conventional oven for 24 hours. The dried herbs were grounded into a powder. The extraction method used was maceration by weighing $5 \mathrm{~g}$ of powdered samples from each region using an analytical balance with a sensitivity of $0.1 \mathrm{mg}$ (Mettler Toledo). The powders were macerated with $50 \mathrm{ml}$ of absolute ethanol pro analytical grade for 24 hours. Filtration was carried out to obtain a liquid extract and then ethanol was added to a volumetric flask of $50.0 \mathrm{ml}$. This sample solution was analyzed using HPLC.

\section{Analysis of ANDR using HPLC}

The reference standards of ANDR were dissolved in methanol HPLC grade to get stock solution with a concentration of $1,000 \mu \mathrm{g} / \mathrm{ml}$. A series of working solutions in certain concentration ranges $(25,50,75,100$, and $125 \mu \mathrm{g} / \mathrm{ml})$ were also prepared from the stock solution. Sample solutions were prepared by transferring $1 \mathrm{ml}$ sample extract into a volumetric flask of $10 \mathrm{ml}$, filled until $10 \mathrm{~mL}$ with ethanol and filtered with $0.45 \mu \mathrm{m}$ filter before being subjected for injection into LC chromatograph. HPLC method for the analysis of reference standards and sample solutions was carried out according to Syukri et al. (2016). HPLC analysis of ANDR was carried out using chromatograph Shimadzu LC-20AD (Kyoto, Japan) equipped with binary gradient pump using injection valve of Rheodyne $7725 \mathrm{i}$ with $20 \mu$ loop. HPLC separation was carried out on Cosmosil $\mathrm{C}_{18}$ column $(250 \times 4.6 \mathrm{~mm}, 5 \mu \mathrm{m})$ using a mobile phase of methanol and water $(6: 4 \mathrm{v} / \mathrm{v})$ and delivered isocratically at a flow rate of $0.8 \mathrm{ml} /$ minutes. The injection volume and wavelength of the wavelength detector were $20 \mu \mathrm{l}$ and 229 $\mathrm{nm}$.

\section{FTIR spectra measurement}

The measurement of FTIR spectra was carried out according to Irnawati et al. (2020b). The powdered A. paniculata samples were placed on a Smart iTR ${ }^{\mathrm{TM}}$ attenuated total reflectance at a mid-infrared region of 4,000-650 $\mathrm{cm}^{-1}$, recorded for 32 scans at a resolution of $8 \mathrm{~cm}^{-1}$.

\section{Data analysis}

The multivariate calibrations were carried out through chemometric software of TQ Analyst ${ }^{\circledR}$ software version 9 (Thermo Fisher Scientific, Inc., Waltham, MA). The multivariate 
calibrations used were PLSR and principal component regression (PCR). HPLC data were used as the actual values and FTIR data were used as a predicted value. The selection of wavenumber regions is based on its capability of giving high coefficient of determination $\left(R^{2}\right)$ and low values of errors, either Root mean square error of calibration (RMSEC) or Root mean square error of prediction (RMSEP).

\section{RESULTS AND DISCUSSION}

In the present research, FTIR spectra combined with multivariate calibrations were used for the quantification of ANDR in herbs of $A$. paniculata. As its property as fingerprint technique, FTIR spectra could be used for selecting specific peaks corresponding to target analytes (ANDR). But, FTIR spectra used as tools for the analysis of ANDR in herbs are nonstandard methods; therefore, the actual values of analytes must be determined using a reference method, namely, HPLC. Quantification of ANDR using HPLC was carried out using external calibration by preparing the linearity curve correlating between concentrations of ANDR ( $x$-axis) and peak area or area under curve ( $y$-axis). The linearity was obtained from five concentrations of standard solutions $(25$, $50,75,100$, and $125 \mu \mathrm{g} / \mathrm{ml})$. From the calibration plot in Figure 2, the $\left(R^{2}\right)$ value for ANDR was 0.99998 , indicating a good linearity with the following equation: $y=50,513.92 \times-16,180.4$.

HPLC, a reference method for analysis of analyte of interest, was utilized for the quantitative estimation of ANDR. Standard and samples showed similar retention time values. Figure 3 shows the HPLC chromatogram, either in ANDR obtained from Sigma-Aldrich (at a concentration of $75 \mu \mathrm{g} / \mathrm{ml}$ ) with retention time 7.140 minutes or in ethanolic extract of $A$. paniculata (AP3) with the retention time of 7.121 minutes (data were not shown). An analyte can be characterized by its retention time, which is not affected by the quantity of injected samples. Table 1 shows the concentrations of analyte (ANDR) in some samples of ethanolic extracts of the $A$.

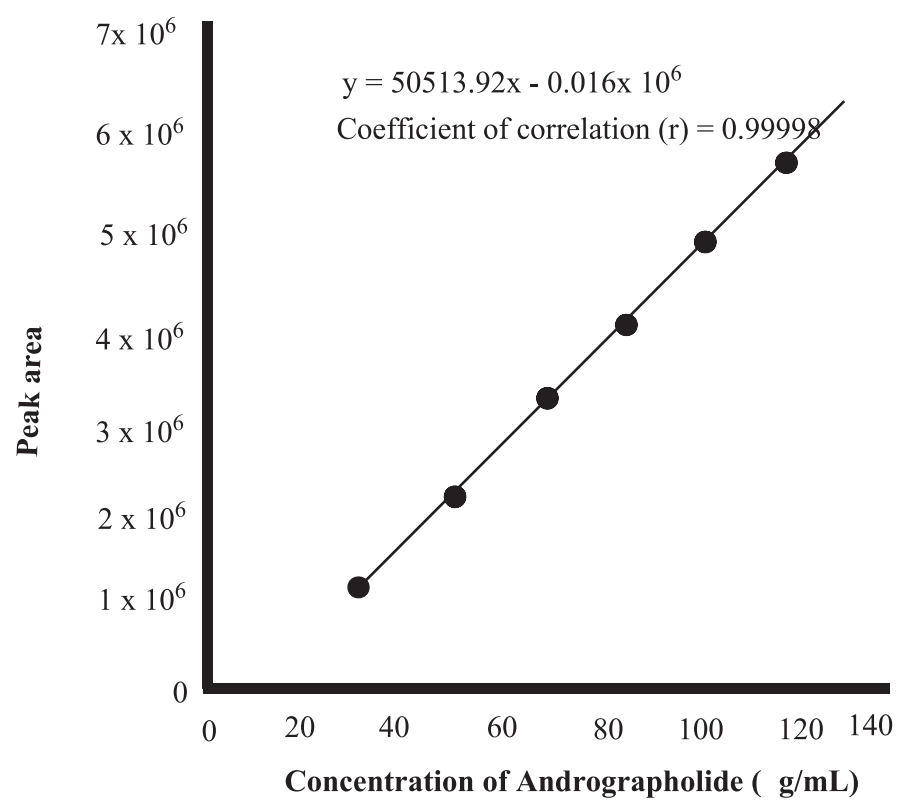

Figure 2. Linear regression curve for correlation between the concentration of andrographolide and area under the curve, as analyzed using HPLC. paniculata herb in some regions. ANDR contents in the analyzed extracts were diverse, mainly due to the differences in season of cultivation, region, age, and time of harvesting (Hossain et al., 2014). The concentrations of ANDR were used as actual values to be correlated with ANDR contents predicted by the FTIR method facilitated with two multivariate calibrations of PCR and PLSR.

Figure 4 shows the FTIR spectra of dried powder of A. paniculata herb from different regions. The main component present in A. paniculata is ANDR. The peak and shoulders shown have originated from the functional groups" absorption present in the evaluated samples. From the analysis, the FTIR spectra showed similar peaks, which can be interpreted as a similar profile in chemical components. The differences in peak intensities caused by different levels of chemical contents could be seen in the dried powders. The peak at (a) $3,286 \mathrm{~cm}^{-1}$ may be due to the presence of stretching vibration of the $\mathrm{O}-\mathrm{H}$ bond. The peaks at (b) 2,919 and (c) $2,851 \mathrm{~cm}^{-1}$ originated from stretching vibrations of $\mathrm{C}-\mathrm{H}$. The group of $\mathrm{C}=\mathrm{O}$ was observed at (d) $1,731 \mathrm{~cm}^{-1}$ with

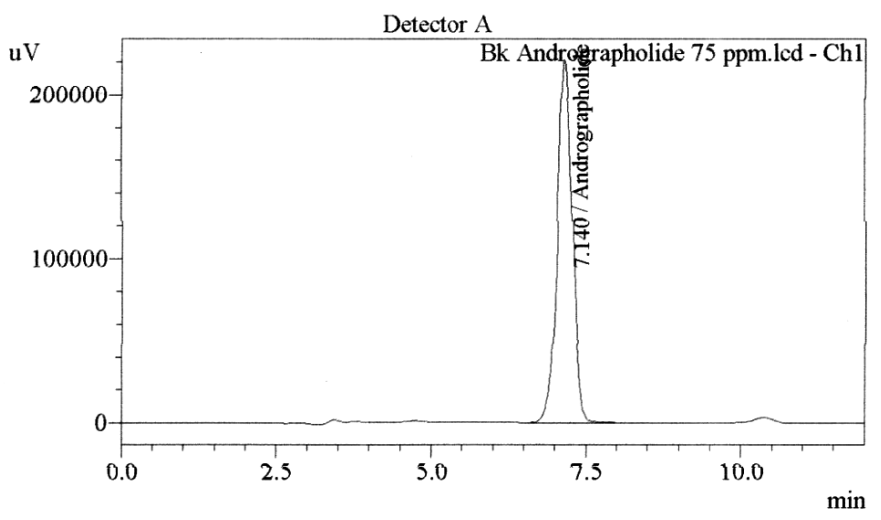

Figure 3. HPLC chromatogram of andrographolide at a concentration of $75 \mu \mathrm{g} /$ $\mathrm{ml}$. HPLC condition, column: Cosmosil $\mathrm{C}_{18}$ column $(250 \mathrm{~mm} \times 4.6 \mathrm{~mm}, 5 \mu \mathrm{m})$; mobile phase: methanol : water $(60: 40)$; flow rate: $0.8 \mathrm{ml} /$ minutes; injection volume: $20 \mu \mathrm{l}$; detector: ultraviolet $229 \mathrm{~nm}$.

Table 1. Levels of andrographolide in herb of A. paniculata from several regions.

\begin{tabular}{cc}
\hline Sample & Concentrations of andrographolide $(\% \boldsymbol{w t} / \boldsymbol{w})$ \\
\hline AP1 & 0.5589 \\
AP2 & 0.4320 \\
AP3 & 0.9565 \\
AP4 & 0.5507 \\
AP5 & 0.7523 \\
AP6 & 0.4372 \\
AP7 & 0.5439 \\
AP8 & 0.7563 \\
AP9 & 0.5373 \\
AP10 & 0.9433 \\
AP11 & 0.6629 \\
AP12 & 0.3900 \\
AP13 & 0.6393 \\
AP14 & 0.5001 \\
AP15 & 0.3694 \\
\hline
\end{tabular}




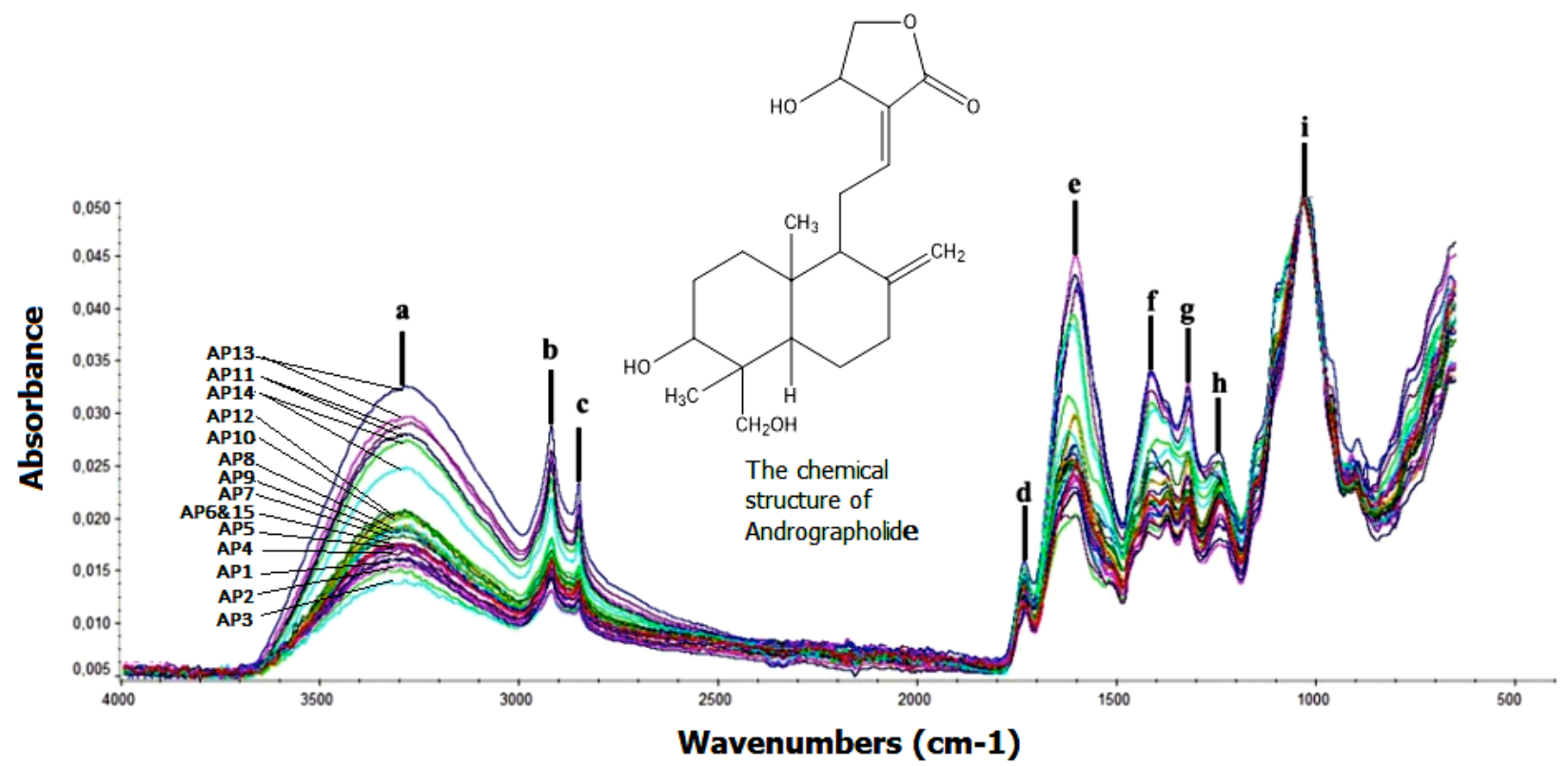

Figure 4. FTIR spectra of dried powder of $A$. paniculata herb from different regions scanned at midwavenumbers of 4,000-650 $\mathrm{cm}^{-1}$. Inset: the chemical structure of andrographolide. AP1-AP3 $=A$. paniculata herb from Bantul, AP4-AP6 and AP15 = A. paniculata herb from Sleman, AP7-AP9 $=A$. paniculata herb from Kulon Progo, AP10 and AP12 = A. paniculata herb from Semarang, AP11 and AP13 = A. paniculata herb from Boyolali, and AP14 = A. paniculata herb from Bogor.

stretching vibration mode, while the peaks at (e) 1,605 and (f) $1,416 \mathrm{~cm}^{-1}$ were coming from $\mathrm{C}=\mathrm{C}$ alkenes and bending vibration of $\mathrm{CH}_{2}$, respectively. The peaks at (g) 1,320 and (h) $1,239 \mathrm{~cm}^{-1}$ were originating from $\mathrm{C}-\mathrm{O}$ in stretching vibration mode. The peak at (i) $1,030 \mathrm{~cm}^{-1}$ may be due to the presence of amine $\mathrm{C}-\mathrm{N}$ stretching vibration (Lestari et al., 2017).

Quantitative analysis of ANDR in herbs of A. paniculata can be difficult in FTIR spectroscopy due to the overlapping spectra of the molecules in the sample. FTIR spectra combined with multivariate calibrations of PCR and PLSR are useful for the quantitative analysis of analytes in complex mixtures (Rohman, 2014). In PLSR and PCR, the variables used during modeling was absorbance values at specific wavenumbers. The absorbance values were then combined to obtain principal components (PCs) and regressed toward actual values obtained by HPLC analysis

The wavenumbers used were selected based on some variations that existed, especially in peak intensities. The FTIR spectra in normal and derivatization modes were compared for modeling. The derivatization of FTIR spectra could make the overlapping peaks be more resolved, but the sensitivity was decreased (Irnawati et al., 2020a). To obtain the best prediction models, the optimizations in terms of the selection of wavenumber regions and the modes of FTIR spectra either in normal or in the first and the second derivatives were optimized (Rohman et al., 2015). The selection of optimization parameters was relied on its capability of giving high $R^{2}$ and low values of errors, either in calibration models (RMSEC) or in prediction models called RMSEP. The lower errors indicated a more precise model, while the higher $R^{2}$ value exhibited the more accurate developed models (Siregar et al., 2018).

Table 2 showed the optimization results of FTIR spectra combined with PLSR and PCR for quantitative analysis of ANDR using normal and derivative spectra at specific wavenumbers.
Table 2. The performance of principal PCR and PLSR for quantitative analysis of $A$. paniculata herb.

\begin{tabular}{|c|c|c|c|c|c|c|}
\hline \multirow{2}{*}{$\begin{array}{l}\text { Multivariate } \\
\text { calibrations }\end{array}$} & \multirow{2}{*}{$\begin{array}{c}\text { Wave } \\
\text { number } \\
\left(\mathrm{cm}^{-1}\right)\end{array}$} & \multirow{2}{*}{ Spectra } & \multicolumn{2}{|c|}{ Calibration } & \multicolumn{2}{|c|}{ Validation } \\
\hline & & & $R^{2}$ & RMSEC & $R^{2}$ & RMSEP \\
\hline \multirow{12}{*}{ PLS } & \multirow{3}{*}{$3,700-665$} & Normal & 0.9894 & 0.026 & 0.7444 & 0.163 \\
\hline & & Derivative 1 & 0.9680 & 0.046 & 0.9324 & 0.068 \\
\hline & & Derivative 2 & 0.9997 & 0.005 & 0.9765 & 0.055 \\
\hline & \multirow{3}{*}{$\begin{array}{c}3,700- \\
2800\end{array}$} & Normal & 0.9957 & 0.017 & 0.4954 & 0.240 \\
\hline & & Derivative 1 & 0.9999 & 0.003 & 0.9361 & 0.075 \\
\hline & & Derivative 2 & 0.9996 & 0.005 & 0.8739 & 0.085 \\
\hline & \multirow{3}{*}{$1,800-665$} & Normal & 0.9772 & 0.039 & 0.6810 & 0.174 \\
\hline & & Derivative 1 & 0.9480 & 0.058 & 0.9075 & 0.076 \\
\hline & & Derivative 2 & 0.9752 & 0.040 & 0.9475 & 0.077 \\
\hline & \multirow{3}{*}{$\begin{array}{c}3,700- \\
2,800 \text { and } \\
1,800-665\end{array}$} & Normal & 0.8573 & 0.093 & 0.7196 & 0.115 \\
\hline & & Derivative 1 & 0.9560 & 0.053 & 0.9200 & 0.071 \\
\hline & & Derivative 2 & 0.9990 & 0.008 & 0.9667 & 0.054 \\
\hline \multirow{12}{*}{ PCR } & \multirow{3}{*}{$3,700-665$} & Normal & 0.9363 & 0.064 & 0.7820 & 0.106 \\
\hline & & Derivative 1 & 0.9374 & 0.063 & 0.8545 & 0.089 \\
\hline & & Derivative 2 & 0.9519 & 0.056 & 0.9127 & 0.085 \\
\hline & \multirow{3}{*}{$\begin{array}{c}3,700- \\
2800\end{array}$} & Normal & 0.7368 & 0.123 & 0.4065 & 0.245 \\
\hline & & Derivative 1 & 0.7168 & 0.126 & 0.1349 & 0.167 \\
\hline & & Derivative 2 & 0.7440 & 0.121 & 0.2566 & 0.159 \\
\hline & \multirow{3}{*}{$1,800-665$} & Normal & 0.8783 & 0.087 & 0.6742 & 0.129 \\
\hline & & Derivative 1 & 0.9137 & 0.074 & 0.8008 & 0.101 \\
\hline & & Derivative 2 & 0.9301 & 0.067 & 0.8719 & 0.095 \\
\hline & \multirow{3}{*}{$\begin{array}{c}3,700- \\
2,800 \text { and } \\
1,800-665\end{array}$} & Normal & 0.7728 & 0.115 & 0.3771 & 0.162 \\
\hline & & Derivative 1 & 0.9054 & 0.077 & 0.8165 & 0.099 \\
\hline & & Derivative 2 & 0.8908 & 0.092 & 0.7573 & 0.109 \\
\hline
\end{tabular}

PLSR using normal spectra at wavenumber region of 3,700-665 $\mathrm{cm}-1$ was used. 
(A)

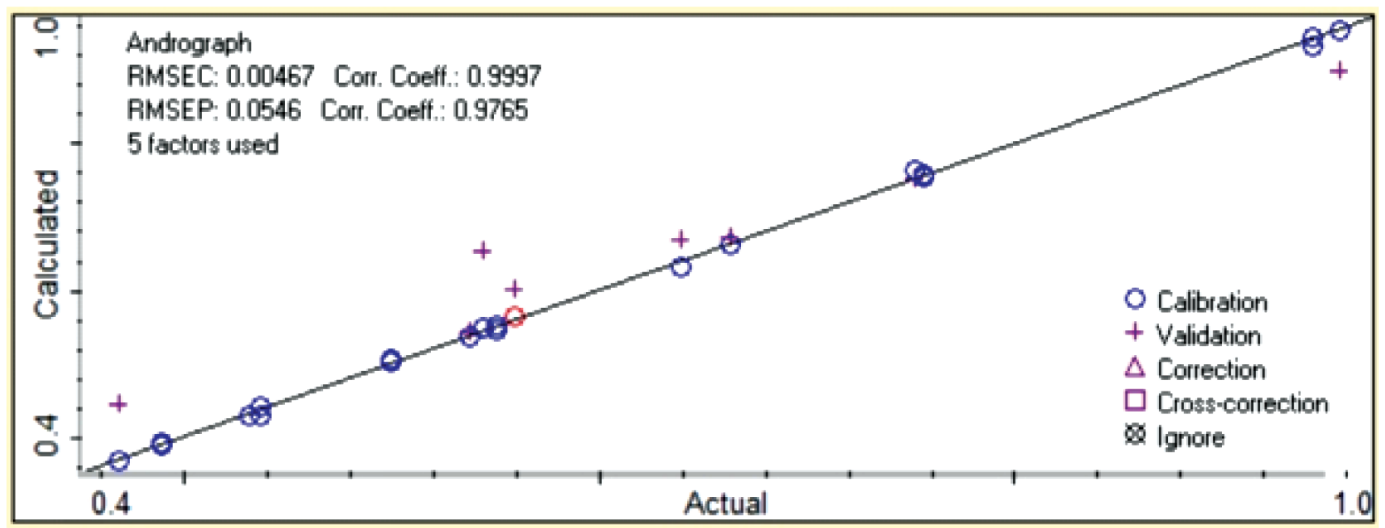

(B)

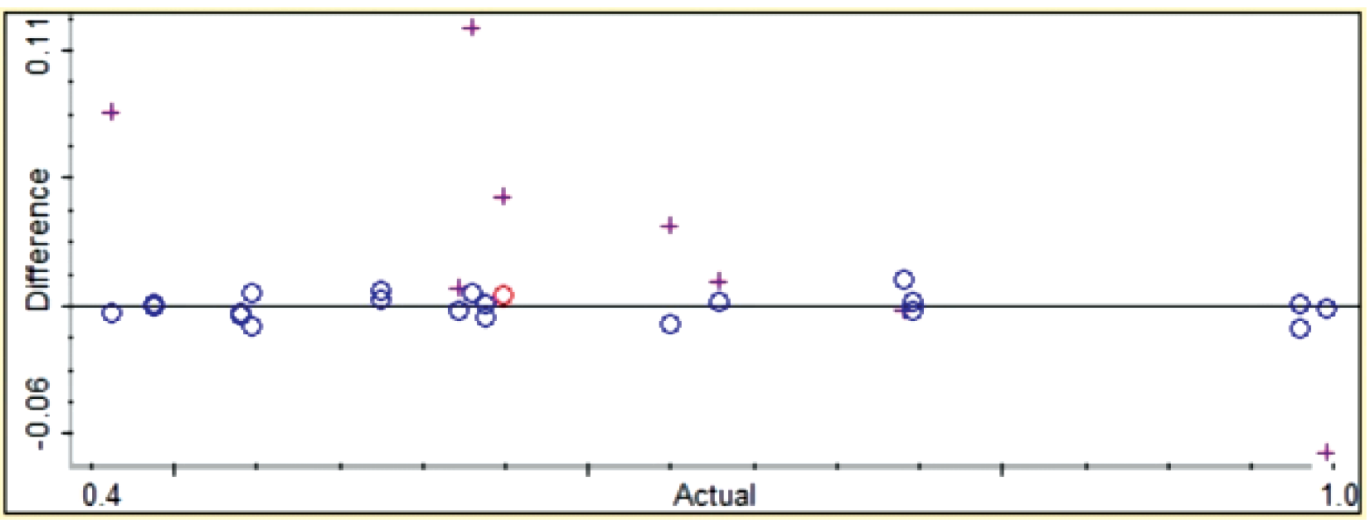

Figure 5. The relationship between actual values ( $x$-axis) of andrographolide and the predicted values of andrographolide ( $y$-axis) in powdered samples of $A$. paniculata using FTIR spectroscopy (A) along with residual analysis (B.).

These results were expressed by $R^{2}$ and RMSEC and RMSEP values. After optimization, PLSR using variables of absorbance values at $3,700-665 \mathrm{~cm}^{-1}$ was finally chosen for the prediction of ANDR because this condition could give the highest $R^{2}$ values of 0.9997 in the calibration model and 0.9765 in the validation model. The values of RMSEC and RMSEP were relatively low, that isi.e., $0.005 \%$ and $0.055 \%$, respectively. These results exhibited that PLSR models offered good accuracy and precision (Miller and Miller, 2010).

Figure 5(A) revealed the scatter plot which explains the correlation between actual ( $x$-axis) and predicted values ( $y$-axis) of ANDR in powder herbs as determined by HPLC and FTIR spectra with the aid of PLSR using the second derivative FTIR spectra at 3,700-665 $\mathrm{cm}^{-1}$. Figure 5(B) showed a residual analysis of the model, and it indicates the difference between the actual values and predicted values to see the error patterns; therefore, the error that occurred during modeling is negligible because all point differences between actual and predicted value falls above and below zero value. The model developed is reliable to predict ANDR content.

\section{CONCLUSION}

The combination of FTIR spectra and PLSR was successfully used for quantification of ANDR using derivative-2 FTIR spectra at $3,700-665 \mathrm{~cm}^{-1}$, with $R^{2}$ for the correlation of actual values and FTIR predicted values of 0.9997 (calibration) and 0.9765 (validation), respectively, with RMSEC (0.005\%) and RMSEP $(0.055 \%)$. As a reference, the HPLC method is useful to determine the contents of ANDR in A. paniculata herb. The levels of ANDR quantified with HPLC were used as actual values during prediction with FTIR spectroscopy.

\section{ACKNOWLEDGMENTS}

The authors acknowledge the Ministry of Research, Technology and Higher Education, Republic of Indonesia, for financial support during this study through the World Class University Program of Universitas Gadjah Mada for financial support of this research by Riset Kolaborasi Indonesia Grant 2019 awarded to Prof. Dr. Abdul Rohman.

\section{AUTHORS' CONTRIBUTIONS}

Hanifah Luthfianasari and Irnawati carried out the research activities, data acquisition, and analyzed data. Abdul Rohman, Sugeng Riyanto, Mohamad Rafi, Bambang Prajogo, Muhammad Bachri Amran designed the research, drafted the manuscript, and made critical thinking on the manuscript.

\section{CONFLICT OF INTEREST}

Authors declare that there are no conflicts of interest. 


\section{FUNDING}

None.

\section{REFERENCES}

Akowuah GA, Zhari I, Mariam A. Analysis of urinary andrographolides and antioxidant status after oral administration of Andrographis paniculata leaf extract in rats. Food Chem Toxicol, 2008; 46(12):3616-20.

Akowuah GA, Zhari I, Mariam A, Yam MF. Absorption of andrographolides from Andrographis paniculata and its effect on $\mathrm{CCl}_{4^{-}}$ induced oxidative stress in rats. Food Chem Toxicol, 2009; 47(9):2321-6.

Akowuah GA, Zhari I, Norhayati I, Mariam A. HPLC and HPTLC densitometric determination of andrographolides and antioxidant potential of Andrographis paniculata. J Food Compost Anal, 2006; $19(2-$ 3):118-26.

Chen HW, Huang CS, Li CC, Lin AH, Huang YJ, Wang TS. Bioavailability of andrographolide and protection against carbon tetrachloride-induced oxidative damage in rats. Toxicol Appl Pharmacol, 2014; 280(1):1-9.

Gu Y, Ma J, Liu Y, Chen B, Yao S. Determination of andrographolide in human plasma by high-performance liquid chromatography/mass spectrometry. J Chromatogr B Analyt Technol Biomed Life Sci, 2007; 854(1):328-31.

Hossain MS, Urbi Z, Sule A, Rahman KMH. Andrographis paniculata (Burm. f.) Wall. ex Nees: a review of ethnobotany, phytochemistry, and pharmacology. Sci World J, 2014; 2014:1-8.

Indrati O, Martien R, Rohman A, Nugroho AK. Employment of ATR-FTIR and HPLC-UV method for detection and quantification of andrographolide. Int J Appl Pharm, 2018; 10(6):135-8.

Irnawati, Riyanto S, Martono S, Rohman A. Determination of sesame oil, rice bran oil and pumpkin seed oil in ternary mixtures using FTIR spectroscopy and multivariate calibrations. Food Res, 2020a; 4(1):135-42.

Irnawati, Riyanto S, Martono S, Rohman A. The employment of FTIR spectroscopy and chemometrics for authentication of pumpkin seed oil from sesame oil. Food Res, 2020b; 4(1):42-8.

Kim N, Lertnimitphun P, Jiang Y, Tan H, Zhou H, Lu Y. Andrographolide inhibits inflammatory responses in LPS-stimulated macrophages and murine acute colitis through activating AMPK. Biochem Pharmacol, 2019; 170:1136-46.

Lestari HP, Martono S, Wulandari R, Rohman A. Simultaneous analysis of curcumin and demethoxycurcumin in Curcuma xanthorriza using FTIR spectroscopy and chemometrics. Int Food Res J, 2017; 24(5):2097-101.

Lu CY, Li CC, Lii CK, Yao HT, Liu KL, Tsai CW. Andrographolide-induced pi class of glutathione S-transferase gene expression via PI3K/Akt pathway in rat primary hepatocytes. Food Chem Toxicol, 2011; 49(1):281-9.

Miller JN, Miller JC. Statistics and chemometrics for analytical chemistry. Pearson Education, North York, ON, 2010.

Mittal SPK, Khole S, Jagadish N, Ghosh D, Gadgil V, Sinkar V. Andrographolide protects liver cells from $\mathrm{H}_{2} \mathrm{O}_{2}$ induced cell death by upregulation of Nrf-2/HO-1 mediated via adenosine A2a receptor signalling. Biochim Biophys Acta, 2016; 1860(11):2377-90.

Rohman A. Spektroskopi inframerah dan kemometrika untuk analisis farmasi [Infrared spectroscopy and chemometrics for pharmaceutical analysis]. Pustaka Pelajar, Yogyakarta, Indonesia, 2014.
Rohman A, Sudjadi, Devi, Ramadhani D, Nugroho A. Analysis of curcumin in Curcuma longa and Curcuma xanthorriza using FTIR spectroscopy and chemometrics. Res J Med Plant, 2015; 9(4):179-86.

Sajeeb BK, Kumar U, Halder S, Bachar SC. Identification and quantification of andrographolide from Andrographis paniculata (Burm. f.) Wall. ex Nees by RP-HPLC method and standardization of its market preparations. Dhaka Univ J Pharm Sci, 2015; 14(1):71-8.

Shivali G, Praful L, Vijay G. A validated Fourier transform infrared spectroscopy method for quantification of total lactones in Inula racemosa and Andrographis paniculata. Phytochem Anal, 2012; 23(2):171-6.

Singh PK, Hasan T, Prasad O, Sinha L, Raj K, Misra N. FTIR spectra and vibrational spectroscopy of andrographolide. Spectroscopy, 2006; 20(5):275-83.

Siregar C, Martono S, Rohman A. Application of Fourier transform infrared (FTIR) spectroscopy coupled with multivariate calibration for quantitative analysis of curcuminoid in tablet dosage form. $\mathrm{J}$ Appl Pharm Sci, 2018; 8(8):151-6.

Syukri Y, Martien R, Lukitaningsih E, Nugroho AE. Quantification of andrographolide isolated from Andrographis paniculata nees obtained from traditional market in Yogyakarta using validated HPLC. Indones J Chem, 2016; 16(2):190-7.

Xu J, Li Z, Cao M, Zhang H, Sun J, Zhao J. Synergetic effect of Andrographis paniculata polysaccharide on diabetic nephropathy with andrographolide. Int J Biol Macromol, 2012; 51(5):738-42.

Xu L, Xiao DW, Lou S, Zou JJ, Zhu YB, Fan HW. A simple and sensitive HPLC-ESI-MS/MS method for the determination of andrographolide in human plasma. J Chromatogr B Analyt Technol Biomed Life Sci, 2009; 877(5):502-6.

Yanfang Z, Xingping L, Zongde Z, Liren C, Yongmin L. Simultaneous determination of andrographolide and dehydroandrographolide in Andrographis paniculata and Chinese medicinal preparations by microemulsion electrokinetic chromatography. J Pharm Biomed Anal, 2006; 40(1):157-61.

Yang M, Wang J, Kong L. Quantitative analysis of four major diterpenoids in Andrographis paniculata by $1 \mathrm{H}$ NMR and its application for quality control of commercial preparations. J Pharm Biomed Anal, 2012; 70(11):87-93.

Zhang SQ, Fan YM. Determination of andrograpolide sodium bisulphite in beagle dog plasma by LC-MS/MS and its application to pharmacokinetics. J Chromatogr B Analyt Technol Biomed Life Sci, 2012; 907(10):173-7.

\section{How to cite this article:}

Rohman A, Luthfianasari H, Irnawati, Riyanto S, Rafi M, Prajogo B, Amran MB. HPLC-FTIR spectroscopy combined with multivariate calibration for analysis of Andrographolide in Andrographis paniculata extract. J Appl Pharm Sci, 2021; 11(05):032-038 


\section{GRAPHICAL ABSTRACT}

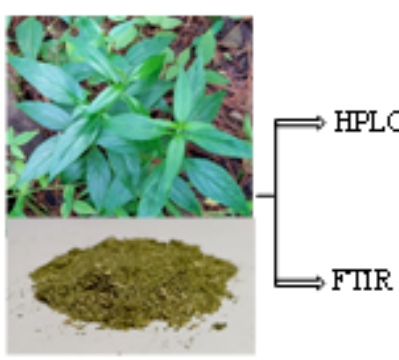

The herbs and powder of Androgrophis poniculata

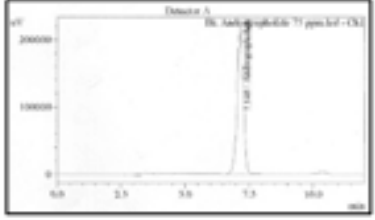

HPLC chromatogram

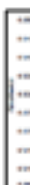

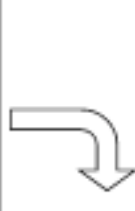

TQAmalyst: $\longrightarrow$

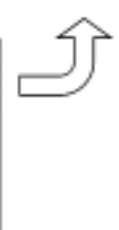

FTIR spectra
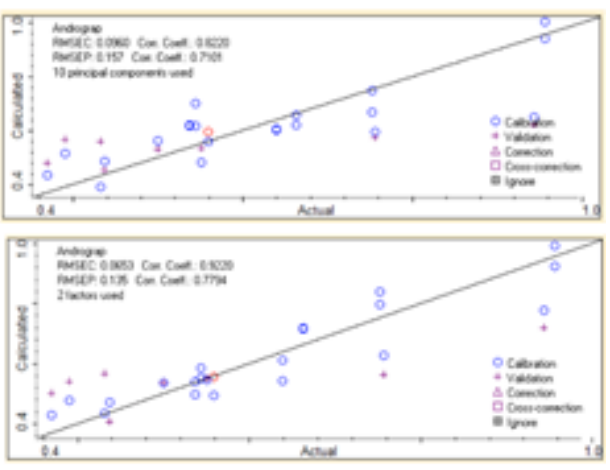

The prediction model

\section{SUMMARY}

Andrographis paniculata or Sambiloto in Indonesia has been known to contain ANDR having some biological activities either in vitro or in vivo. FTIR spectroscopy could be developed as an alternative technique to predict the levels of ANDR without sample preparation during analysis. PLSR is successfully applied for correlating the actual contents of ANDR as quantified using the reference method of HPLC and FTIR predicted values. 